Aksaray University
Journal of Science and Engineering
e-ISSN: 2587-1277
http://dergipark.gov.tr/asujse
http://asujse.aksaray.edu.tr

Research Article

\title{
An Investigation with Neural Network of Heat Loss for Optimum Insulation
}

Bekir Cirak $^{*}$

Siirt University, Engineering Faculty, Department of Mechanical Engineering, Kezer Campus, Siirt, Turkey

$\begin{array}{llll}\text { •Received Date: } 08 \text { Mar } 2017 & \text { Revised Date: } 20 \text { Apr } 2017 & \text { •Accepted Date: } 24 \text { Apr } 2017 & \text { •Published Online: } 07 \text { Jul } 2017\end{array}$

\begin{abstract}
In this study, two different artificial neural network models were used for insulation and noninsulation of the heating pipes used for heating in buildings and two different artificial neural networks (YSA) models for the insulated and non-insulated states of the building walls. 3-layer forward feed in YSA models designed for these situations and a back-propagation model is preferred. The sigmoid transfer function is used in the hidden layer and the linear transfer function is used in the output layer. Back propagation artificial neural network topology is preferred as YSA model and the data were presented to the network in normalized form. The temperature values obtained from the network are compared with the measured temperature values and the results are very close to one another. In this way, the use of artificial neural network method for estimation of 4 different internal models, definition of models and the prediction power has increased. In the random and periodic time interval, the inner plaster thickness is $2 \mathrm{~cm}$, the outer plaster thickness is $3 \mathrm{~cm}$ and according to the wall width of $17 \mathrm{~cm}$, $10 \mathrm{~cm}$ thick insulation (xps material insulated) and according to the non-insulated wall parameters The statistical data generated from this table that is not based on a nonlinear formula, ie, YSA, is introduced to the network structure and the results obtained by testing from the YSA model in the Matlab environment after training were compared and values very close to each other were determined. Again, in a random and periodic time interval insulated with $100 \mathrm{~mm}$ pipe size (insulated stapler material) and the values obtained from the table according to the uninsulated pipe parameters and the results from the YSA model were compared and compared very close values have been determined.
\end{abstract}

\section{Keywords}

Artificial Neural Network, Inside and Outside Wall, Insulation, Loss of Heat

*Corresponding Author: Bekir Cirak, bekircirak@mynet.com 


Aksaray University
Journal of Science and Engineering
e-ISSN: 2587-1277
http://dergipark.gov.tr/asujse
http://asujse.aksaray.edu.tr

Research Article

\title{
Optimum Yalıtım için Kayıpların Yapay Sinir Ağları ile İncelenmesi
}

\author{
Bekir Çırak ${ }^{*}$
}

Siirt Üniversitesi, Mühendislik Fakültesi, Makina Mühendisliği, Keser Yerleşkesi, Siirt, Türkiye

•Gönderi Tarihi: 08 Mar $2017 \quad$ Düzeltme Tarihi: 20 May $2017 \quad$ •Kabul Tarihi: 24 May $2017 \quad$ •Çevrimiçi Yayın Tarih: 07 Tem 2017

\section{Özet}

Burada yapılan çalışmada binalarda 1sıtma için kullanılan kalorifer borularının yalıtımlı ve yalıtımsız durumları için iki ayrı yapay sinir ağı modeli ve bina duvarlarının yalıtımlı ve yalıtımsız durumları için iki ayrı yapay sinir ağı (YSA) modeli olmak üzere toplamda 4 ayrı model kullanılmıştır. Bu durumlar için tasarlanan YSA modellerinde 3 katmanlı ileri beslemeli ve geri yayılımlı bir model şekli tercih edilmiştir. Gizli katmanda sigmoid transfer fonksiyonu, çıkış katmanında ise doğrusal transfer fonksiyonu kullanılmıştır. YSA ağ topolojisi olarak geri yayılımlı yapay sinir ağı topolojisi tercih edilmiş ve veriler normalize edilerek ağa sunulmuştur. Ağdan elde edilen sıcaklık değerleri gerçekte ölçülen sıcaklık değerleri ile mukayese edilmiş ve sonuçların biri birlerine çok yakın olduğu görülmüştür. Bu durumda 4 farklı iç modelin tahmini için yapay sinir ağları metodunun kullanımı, modellerin tanımı ve tahmin etme gücünü artırmıştır. Rastgele ve periyodik zaman aralığı içinde iç sıva kalınlığ $2 \mathrm{~cm}$, dış sıva kalınlığ $3 \mathrm{~cm}$ olan ve $17 \mathrm{~cm}$ duvar genişliğine göre, ayrıca $10 \mathrm{~cm}$ kalınlığında yalıtımlı (xps malzeme yalıtımlı) ve yalıtımsız duvar parametrelerine göre tablodan alınan değerler YSA ağ yapısına tanıtıldıktan sonra ve eğitildikten sonra Matlab ortamında YSA modelinden test edilerek alınan sonuçlar karşılaştırılmış ve birbirine çok yakın değerler tespit edilmiştir. Yine rastgele ve periyodik zaman aralığı içinde $100 \mathrm{~mm}$ boru boyutuna göre yalıtımlı (stropiyer malzeme yalıtımlı) ve yalıtımsız boru parametrelerine göre tablodan alınan değerler ile YSA modelinden alınan sonuçlar karşılaştırılmış ve biribirine çok yakın değerler tespit edilmiştir.

\section{Anahtar Kelimeler}

Yapay Sinir Ağları, İç ve Dış Duvar, Yalıtım, Isı Kaybı

*Sorumlu Yazar: Bekir Çırak, bekircirak@mynet.com 


\section{GIRIŞ̧}

Yalıtımla tasarruf edilen enerji en temiz enerjidir. Günümüzde hiçbir birey ya da topluluk parasını ödemeye hazır olsa bile enerji israfında özgür değildir. Ülkemizin ekonomik konumu dikkate alındığında enerji ithali için harcanan dövizden sağlanacak tasarrufun önemi ortadadır. Yalıtımlı ve yalıtımsız duvardaki 1sı kayıpları ile daha yüksek sıcaklık farklarının olduğu tesisattaki ısı kayıpları göz önüne alındığında yalıtımın ne kadar önemli olduğu görülmektedir. Günümüzde ülkelerin enerji politikalarında, enerji tasarrufu önemli bir konudur. Sınırlı enerji kaynakları, fosil yakıtların kullanımı sonucu oluşan çevre kirliliği, enerji ihtiyacının büyük bir bölümünün ithal edilmesi, yakıt maliyetleri, enerji tasarrufunu zorunlu hale getirmiştir. Ülkemizdeki enerji tüketiminin önemli bir kısmını oluşturan binalardaki ısı kayıpları, binalara 1S1 yalıtımının uygulanması ile azaltılabilir. Isınma döneminde, sıcaklığın yüksek olduğu iç ortamdan dış ortama doğru bir 1sı kaybı meydana gelir. Yalıtım, yapı elemanlarından gerçekleşen 1sı kaybını azaltır. Kullanılan yalıtım malzemesinin kalınlığı 1sıl konfor ve enerji tasarrufu açısından oldukça önemlidir. Çünkü düşük yalıtım kalınlığg 1sının içeriden dışarıya ya da dışarıdan içeriye daha fazla geçmesine neden olur ve sonuçta 1 sıl konfor ve enerji tasarrufu üzerinde olumsuz bir etki oluşturur.

Binalar için enerji tüketiminin minimum değerlere düşürülmesinde ulusal düzenlemeler getirilmesi bir zorunluluktur. Bu nedenle Türkiye'nin bu yöndeki ihtiyaçları düşünülerek 1999 yılında "Binalarda 1sı yalıtım kuralları" (TS 825) belirlenmiştir. TS 825'e göre Türkiye için dört farklı derece belirlenmiş ve bu bölgeler Şekil 1'de gösterilmiştir. Binaların 1sı yükü ihtiyaçlarını belirleyen en önemli parametre iklim şartlarıdır. $15^{\circ} \mathrm{C}$ taban sıcaklığı ve $20^{\circ} \mathrm{C}$ iç ortam sıcaklığ için DD değerleri birinci bölge için 1500'den daha az, dördüncü bölge için 4500'den daha fazladir.

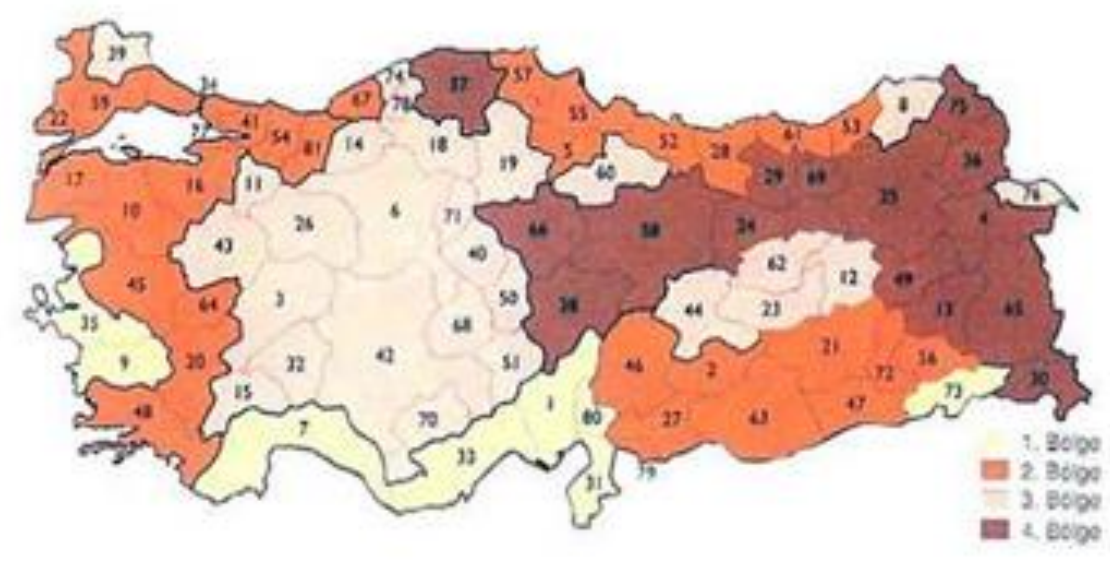

Şekil 1. Türkiye'nin iklim bölgeleri (TSE 825) 
İnsanlığın gelişimi ile beraber ihtiyaçlarda çeşitlenerek artmış ve bu durum beraberinde çeşitlenerek artan bu ihtiyaçların enerjiyle karşılanması mecburiyetini doğurmuştur. Avrupa ülkeleri enerji kaynakları bakımından fakir ülkeler arasında yer almaktadır. Ancak enerji kaynakları bakımından zengin olmak yeterli değildir. Bu kaynakların ekonomik ve etkin kullanılması ile enerji sorununa çözüm bulunabilecektir. Bu durum enerji tesisatlarının ve binaların yalıtımlarını ve izolasyonlarını gerektirir. Yalıtımla sağlanacak olan enerji tasarrufunun önemi giderek artmaktadır [1].

Yapay sinir ağları kavramı beynin çalışma ilkelerinin sayısal bilgisayarlar üzerinde taklit edilmesi fikri ile ortaya çıkmış ve ilk çalışmalar beyni oluşturan biyolojik hücrelerin ya da literatürdeki ismiyle nöronların matematiksel olarak modellenmesi üzerinde yoğunlaşmıştır. Yapay sinir ağlarının gerçek dünya problemlerine adapte edilebilir olması da avantajlarından bir tanesidir [2].

Yapay sinir ağları insan beyninin işleyiş şeklinden yola çıkmış olsa da henüz beynin hızına ulaşamamasına rağmen, karmaşık eşleştirmelerin hassas bir biçimde gerçekleşebilmesi ve yapısal gürbüzlüğe sahip olmaları nedeniyledir ki gün geçtikçe uygulama alanları genişlemektedir. Yapay sinir ağlarının modelleri birbirinden bağımsız ve paralel olarak çalışabilen proses elemanlarının hiyerarşik bir şekilde organizasyonundan oluşur. Girdi elemanı bir dış kaynaktan gelebileceği gibi, diğer bir sinirden de gelebilir. Bir sinir hücresine birden fazla girdi gelebilir [3].

Keleşoğlu ve Fırat yaptıkları bir çalışmada tuğla duvardaki yalıtım hesaplarını yapay sinir ağları ile incelemişlerdir [4]. Daha önce yapılan çalışmalar incelendiğinde Dombaycı vd. Farklı enerji kaynaklarının kullanılması durumunda dış duvarları için optimum yalıtım kalınlığını sıcaklık derecesi-gün sayısını esas alarak hesaplamışlardır. Enerji kaynağı olarak kömür kullanıldığında optimum yalıtım kalınlığını incelemişlerdir [5]. Bolattürk, Isparta bölgesindeki binaların duvar ve çatı döşemeleri için optimum yalıtım kalınlıkları ve enerji tasarruflarını araştırmıştır. Binaların dış duvarlarındaki optimum yalıtım kalınlığı yıllık ısıtma ve soğutma yüklerine dayandırarak analiz etmiştir [6]. Çomaklı ve Yüksel Erzurum, Kars ve Erzincan gibi Türkiye'nin en soğuk üç şehri için optimum yalıtım kalınlığın sayılarını esas alarak araştırmışlardır [7]. Öztuna, Edirne ilinde optimum duvar yalıtım kalınlığının enerji tasarrufuna etkisini derece gün sayısını kullanarak incelemiştir [8].

Literatürdeki çalışmalara kıyasla burada yapılan çalışmanın farkı gerek duvar gerekse boru yalıtım kalınlıklarının yapay sinir ağları yöntemi ile tahmin edilmesidir. Bunun için yalıtımlı ve yalıtımsız olmak üzere 4 ayrı model kurulmuş olmasıdır. Bu modellere göre minimum hata 
ile 4 ayrı kalınlık miktarının tahmini yapılmıştır. Optimum kalınlık değeri simülasyonla yakalanmaya çalışılmıştır.

\section{ISI TRANSFERI}

Isının geçişi olarak da tanımlanan günümüzde 1Sı transferinin teknik ve bilimsel ilkeler doğrultusunda oluşması istenir. Çünkü enerjinin bir parçası olarak ısının üretildiği kadar tüketilmesi ve en az kayıpla kullanılması gerekmektedir. Isı ve 1sı kaynaklarının ekonomik ve etkin kullanılması ile enerji sorununda çözümün bir parçasıdır. Bu durum enerji tesisatlarının ve binaların yalıtımlarını ve izolasyonlarını gerektirir. İnsan sağlığı için zararlı olan bu gazlar, yakıt tüketiminin artmasına bağlı olarak artış göstermektedir [9].

\subsection{Isı Yalıtımı}

Yalıtım malzemesi, dış ortam ile iç ortam arasında 1sı bağımsızlı̆̆ını artıran, 1sı kaçaklarını önleyen, günümüz 1S1 ekonomisinin temelini oluşturan hayati bir malzemedir. İç ortamın 1sıtılmasında dengeli bir 1sı oluşumu sağlayarak stabil bir ısıtma sağlarlar. Bu konuda yalıtım malzemesinin cinsi ne olursa olsun 1sı geçirgenlik katsayısı ve yalıtım gücü önemlidir. Tesisatlar da ısıtma borularının geçtikleri ortam sıcaklıkları da dikkate alınmalıdır. Yalıtım kalınlığı uygunluğu da dış ortam sıcaklığı, bina duvar yapısının katmanları, yalıtım malzemesinin özellikleri gibi unsurlardan etkilenmektedir. Bu hususların hepsi dünyada ISO ve Türkiye'de TSE tarafından norm hale getirilerek disipline edilmiştir. Ancak yalıtım kültürü ve tekniği arttıkça bu norm değerler de değişmektedir. Hatta yalıtım ve malzemesinin kanserojen özellik taşıyıp taşımadığı bile tartışılmaktadır. TSE ye göre binalarda iç ortam sıcaklığının18-20 ${ }^{\circ} \mathrm{C}$, duvar sıcaklığının $16-18{ }^{\circ} \mathrm{C}$ olması, iç ortam sıcaklığı ile dış ortam sıcaklığı arasındaki farkın 30-40 ${ }^{\circ} \mathrm{C}$ olması gerekmektedir. Ancak bu normlar, gerçekte tam sağlanamamaktadır. Burada yalıtımın önemi büyüktür. Ancak bir gerçek daha vardır ki, yalıtımın kaliteli ve hassas olması yalıtım maliyetini ve inşaat ekonomisini artırmaktadır [9].

\section{YAPAY SİNIR AĞLAR}

Yapay Sinir Ağları, insan beynindeki nöronlara benzer olarak meydana getirilen yapay nöronların değişik bağlantı geometrisi ile birbirlerine bağlanmasıyla oluşan sistemlerdir. Şekil 2'de gösterilen bir sinir hücresi kendisine gelen giriş değerlerinin ağırlıklı toplamını aldıktan sonra bir aktivasyon fonksiyonundan geçirerek bir çıktı değer oluşturur. Aktivasyon fonksiyonu doğrusal olabileceği gibi YSA'nın amacı gereği genelde doğrusal olmayan transfer fonksiyonları tercih edilirler [10].

En yaygın transfer fonksiyonları doğrusal fonksiyon, eşik fonksiyonu ve sigmoid fonksiyonlarıdır. Şekil 3'de ileri beslemeli bir YSA modeli görülmektedir. 


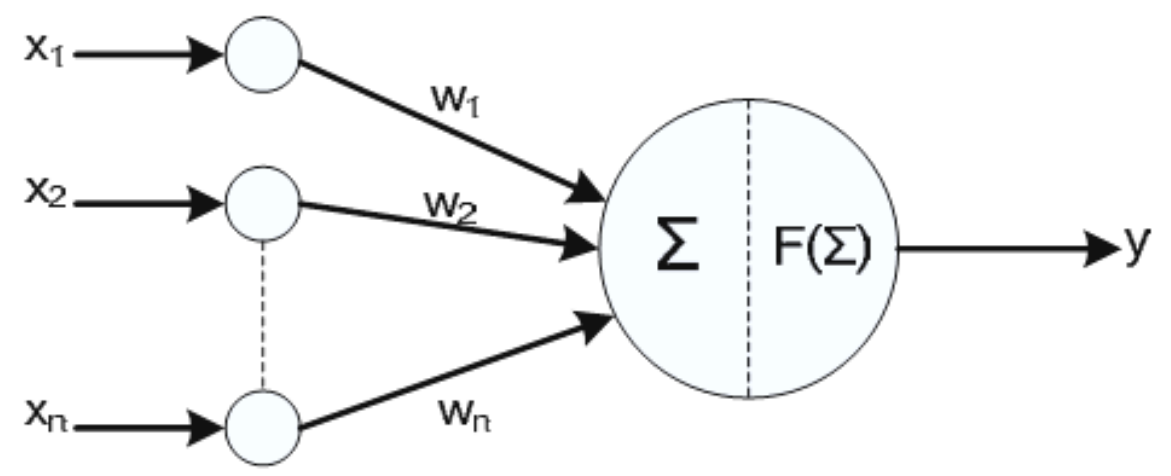

Şekil 2. Nöronun yapısı

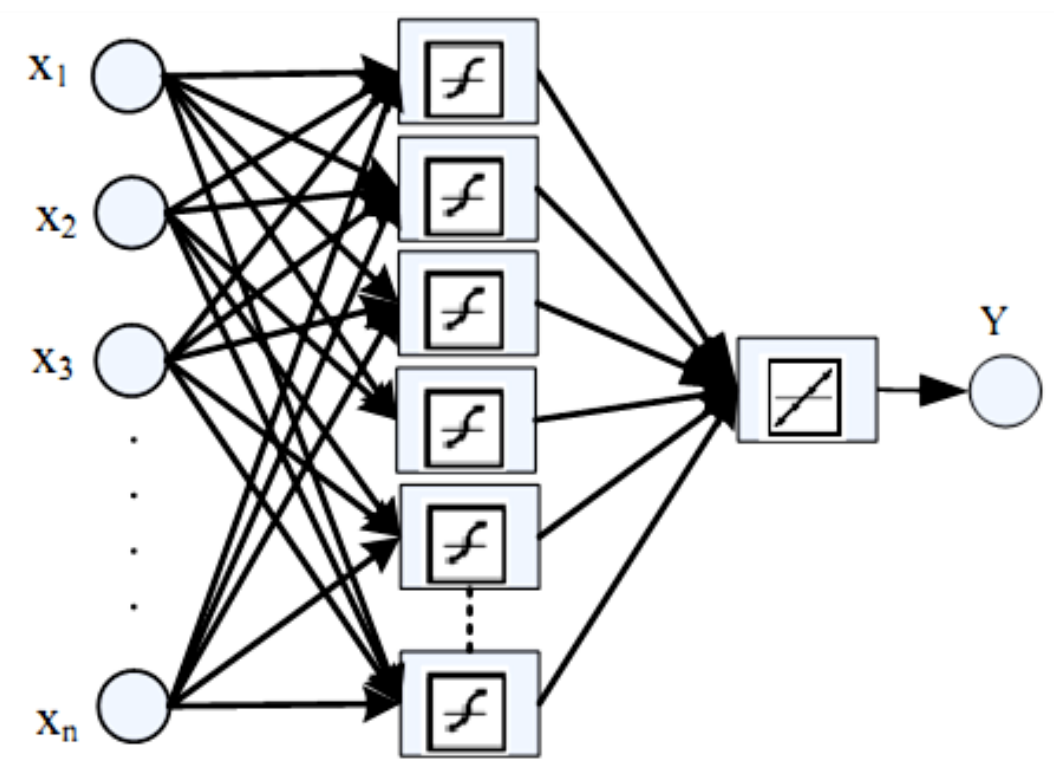

$\begin{array}{lll}\text { Giriş katmanı } & \text { Gizli Katman } \\ & \text { Şekil 3. YSA modeli }\end{array}$

\section{1. Çok Katmanlı Sinir Ăğı}

Yapay sinir ağlarının modelleri birbirinden bağımsız ve paralel olarak çalışabilen proses elemanlarının hiyerarşik bir şekilde organizasyonundan oluşur. Girdi elemanı bir dış kaynaktan gelebileceği gibi, diğer bir sinirden de gelebilir. Bir sinir hücresine birden fazla girdi gelebilir. Birden fazla girdilerin olduğu sinir hücresi yapısı Şekil 4'de olduğu gibidir. Her bir bireysel girdi $\mathrm{p}_{1}, \mathrm{p}_{2}, \mathrm{p}_{3}, \ldots, \mathrm{p}_{\mathrm{R}}, \mathrm{W}$ ağırlık matrisinin $\mathrm{w}_{1,1}, \mathrm{w}_{1,2}, \ldots, \mathrm{w}_{1, \mathrm{R}}$ uygun elemanlarıyla ağırlıklandırılmıştır. $\mathrm{Bu}$ çalışmada kullanılacak olan ağ tipi çok girişli ağ yapısını oluşturmaktadır [11].

Yapay sinir ağlarının parametrelerinin güncellenmesi için, en çok kullanılan yöntem hata geriye yayma yöntemidir. Ses tanıma problemlerinden nonlineer sistem tanılama ve denetimi problemlerine kadar yapay sinir ağları ile çözüm üretilen birçok alanda başarı ile kullanılan bu yöntem, kuadratik bir maliyet fonksiyonunun zaman içinde, ağ parametrelerinin uyarlanması ile minimizasyonuna dayanmaktadır. Bu eğitim metodu hataların geri yayılması veya delta kuralının genelleştirilmesi olarak da bilinir. 


\section{Girdiler}

\section{Çok girişli sinir hücresi}

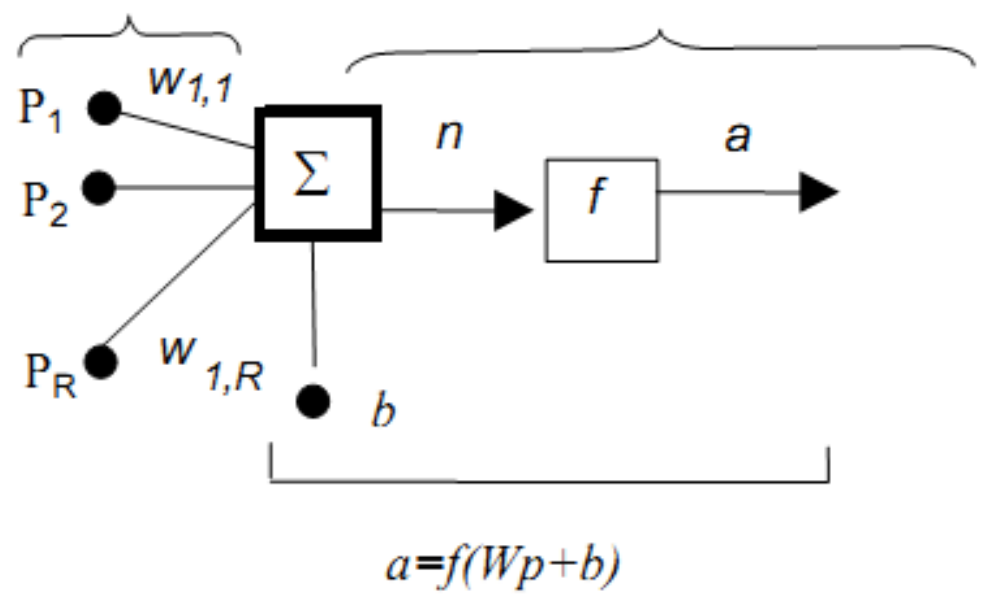

Şekil 4. Çok girişli sinir ağı

İleri besleme sırasında, her girdi birimi, girdi sinyaline ulaşır ve gizli katmanlardan bu sinyaller yayılır. Her bir gizli katman onun aktivasyonunu hesapladıktan sonra, sinyalini çıktı birimine gönderir. Çıktı katmanı da gelen sinyalin aktivasyonunu hesaplar ve ağın çıktı değerini oluşturur [12].

\subsection{YSA Modelinin Eğitimi ve Performansı}

Bir YSA modelinin performansı, gerçek çıktı değerleri ile YSA modelinin oluşturduğu çıktı değerleri arasındaki sapma (hata) miktarının azlığına bağlıdır. Bu hata miktarlarının analizi için üç istatistiksel değer kullanılmıştır. Bunlar RMS istatistiksel hata miktarı (root-mean-squared), $\mathrm{R}^{2}$ (mutlak değişim yüzdesi), OYH (ortalama yüzde hata) değerleridir. Çentik faktörü çıktı değerine göre bu hata miktarları aşağıdaki formüllerle hesaplanır [12].

$$
\begin{array}{ll}
\text { İstatistiksel Hata Miktarı; } & \mathrm{RMS}=\left[1 / p \sum_{j}\left|t_{j}-o_{j}\right|^{2}\right]^{1 / 2} \\
\text { Mutlak Değişim Yüzdesi; } & \mathrm{R}^{2}=1-\left[\frac{\sum_{j}\left(t_{j-} o_{j}\right)^{2}}{\sum_{j}\left(o_{j}\right)^{2}}\right] \\
\text { Ortalama yüzde Hata; } & \text { OYH } \%=\frac{\sum_{j}\left(\frac{t_{j-o} o_{j}}{t_{j}} \times 100\right)}{p}
\end{array}
$$

\subsection{YSA Modelinde Test}

Eğitme işlemlerinden sonra YSA modelinden elde edilen sonuçlarla teorik (gerçek) hesap sonuçları istatiksel hata miktarına göre Microsoft Excel'de karşılaştırılır. İstatistiksel hata analizlerinde eğitim ve test verilerinin performansı birlikte değerlendirilir.

\section{MATERYAL VE YÖNTEMLER}

\subsection{Duvar Yapısı}

Buradaki uygulamada, enerji tasarrufunu en çok sağlayan ve en çok tercih edilen duvar tipi olan sandviç duvar tipi tercih edilmiştir. Yalıtımlı ve yalıtımsız duvarlar için yapılan 
hesaplamalarda, iklim koşulları göz önünde bulundurularak İç ortam sıcaklığı $20^{\circ} \mathrm{C}$, dış ortam sıcaklığ $1-8{ }^{\circ} \mathrm{C}$ seçilmiştir.

\subsubsection{Yalıtımsız Duvar Yapısı}

Yalıtımsız duvar bileşenleri, $2 \mathrm{~cm}$ iç sıva, $17 \mathrm{~cm}$ yatay delikli tuğla ve $3 \mathrm{~cm}$ dış sıvadan oluşmaktadır. Uygulamalarda kullanılan yalıtımsız duvarın yapısı Şekil 5'de gösterilmiştir.

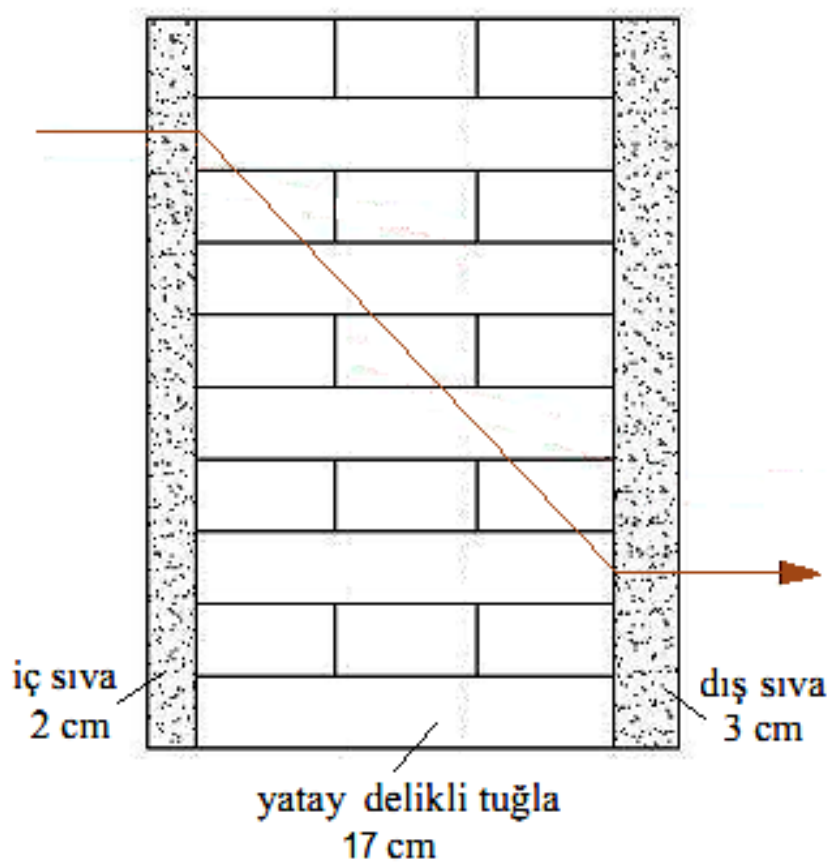

Şekil 5.Yalıtımsız duvar yapısı

\subsubsection{Yalıtımsız duvar için YSA}

Problem için geri yayılımlı yapay sinirağı tercih edilmiştir. Bu ağda 1 giriş katmanı, 1 ara katman ve1 çıkış katmanı kullanılmıştır. Girdi katmanında beş işlem elamanı bulunmaktadır. Şekil 6'da görüldüğü gibi ara katmanda 9 adet yapay nöron kullanılmıştır. Ağın çıkışı ise iç duvar sıcaklığıdır.

Ağın girdi elemanlarına rastgele çeşitli değerler verilerek oluşturulan eğitim ve test setinde 60 adet örnek bulunmaktadır. Bu örneklerin 30 adedi eğitim için diğer 30 adedi ise test için kullanılmıştır. Yalıtımsız duvar için yapılan 1-a uygulamada yalıtım değerleri kullanılmayarak. Giriş ve çıkış değerleri normalize edilmiş ve ağa tanıtılmıştır. Çizelge1'de görüldüğü gibi çeşitli ağ yapıları ve öğrenme oranları denenerek en doğru sonuç elde edilmeye çalışılmıştır. Yapılan denemeler sonucunda 9 nörondan oluşan bir ara katman uygun görülmüş, momentum katsayısı 0.979 ve öğrenme oranı 0.85 alındığında ağ daha uygun sonuçlar vermiştir. 


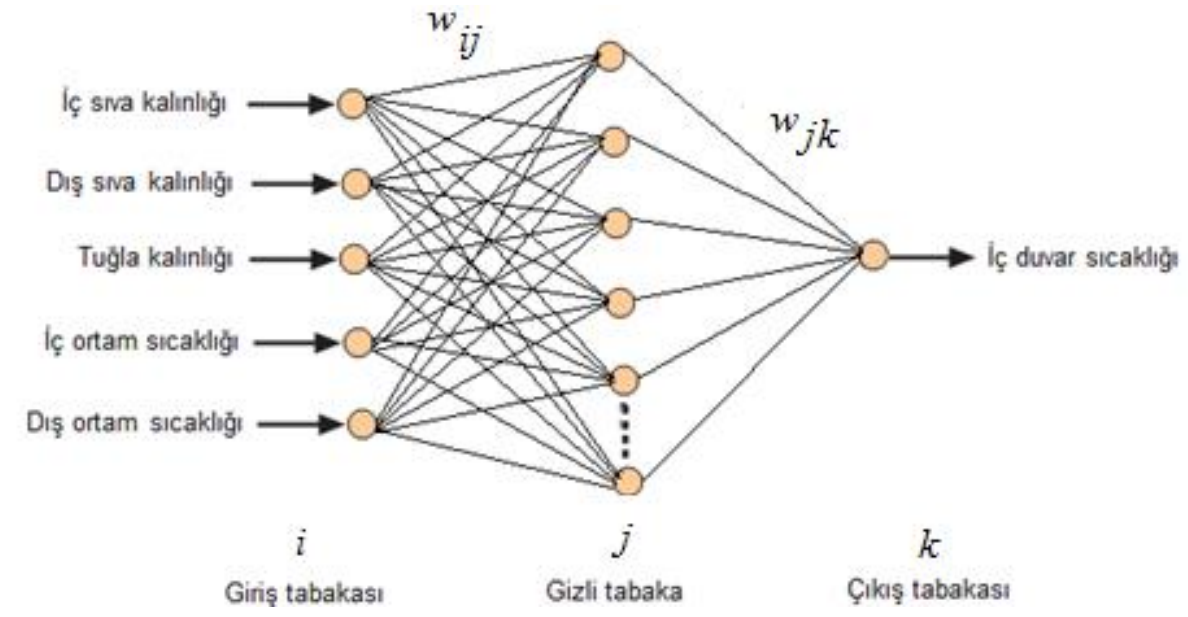

Şekil 6. Yalıtımsız duvar için YSA modeli ă̆ yapısı

Ağın eğitimi tamamlandıktan sonra ağın performansını test etmek amacıyla eğitim setindeki örneklerden tamamen farklı değerler kullanılarak ağ test edilmiştir. Ağın test setinde kullanılan örnekler ve sonuçların karşılaştırılması Çizelge 3'de verilmiştir. Yapay sinir ağını eğittikten ve test ettikten sonra problem için verilen değerler ağa sunulursa elde edilen duvar iç yüzey sıcaklığı $17.056{ }^{\circ} \mathrm{C}$ olarak bulunur. Bu problemin sayısal çözümü sonucunda elde edilen duvar iç yüzey sıcaklığg $17.00{ }^{\circ} \mathrm{C}$ 'dir [9].

Çizelge 1. Yalıtımsız duvar için YSA da kullanılan eğitim ve test değerleri (İlk 30 değer YSA eğitimi, son 30 değer ise YSA testi için kullanılmıştır)

\begin{tabular}{|c|c|c|c|c|c|c|}
\hline No & $\begin{array}{l}\text { İç Sıva } \\
\text { Kalınlığ } \\
(\mathrm{m})\end{array}$ & $\begin{array}{c}\text { Dış Sıva } \\
\text { Kalınlığ } \\
(\mathrm{m})\end{array}$ & $\begin{array}{c}\text { Giriş } \\
\text { Tuğla } \\
\text { Kalınlığı } \\
\text { (m) }\end{array}$ & $\begin{array}{c}\text { İç Ortam } \\
\text { Sicaklığ } 1 \\
\left({ }^{\circ} \mathrm{C}\right)\end{array}$ & $\begin{array}{c}\text { Diş Ortam } \\
\text { Sicaklığ1 } \\
\left({ }^{\circ} \mathrm{C}\right)\end{array}$ & $\begin{array}{c}\text { Çıkış } \\
\text { İç Duvar } \\
\text { Sıcaklığ } 1 \\
\left({ }^{\circ} \mathrm{C}\right)\end{array}$ \\
\hline 1 & 0.01 & 0.03 & 0.15 & 18 & -6 & 8.5 \\
\hline 2 & 0.015 & 0.01 & 0.19 & 20 & -8 & 10.5 \\
\hline 3 & 0.02 & 0.025 & 0.17 & 19 & -9 & 18.5 \\
\hline 4 & 0.015 & 0.015 & 0.19 & 22 & -7 & 12.54 \\
\hline 5 & 0.01 & 0.03 & 0.15 & 21 & -10 & 14.5 \\
\hline 6 & 0.02 & 0.02 & 0.17 & 18 & -8 & 16.5 \\
\hline 54 & 0.015 & 0.025 & 0.19 & 19 & -9 & 18.5 \\
\hline 55 & 0.02 & 0.01 & 0.15 & 21 & -7 & 20 \\
\hline 56 & 0.01 & 0.015 & 0.17 & 20 & -8 & 19.5 \\
\hline 57 & 0.015 & 0.02 & 0.19 & 22 & -10 & 18 \\
\hline 58 & 0.02 & 0.025 & 0.17 & 21 & -9 & 19 \\
\hline 59 & 0.01 & 0.015 & 0.15 & 19 & -6 & 10.5 \\
\hline 60 & 0.015 & 0.03 & 0.19 & 18 & -8 & 8.5 \\
\hline
\end{tabular}

Aktivasyon fonksiyonu olarak "tangent sigmoid fonksiyonu”, ağın eğitilmesi için öğrenme tipi olarak "danışmanlı öğrenme" uygulanmıştır. Bu parametreler kullanılarak MATLAB'ta hazırlanan programda YSA eğitilir. Matlab programı ağırlık değerlerini rastgele belirleyip her bir örneği sırasıyla ağa sunarak çalışmaktadır. Bu ağın iterasyona bağlı hata değiş̧imi Şekil 7'de 
verilmiştir. Şekil 7 incelendiğinde yapılan YSA modelinin performansının oldukça iyi olduğu görülmektedir.

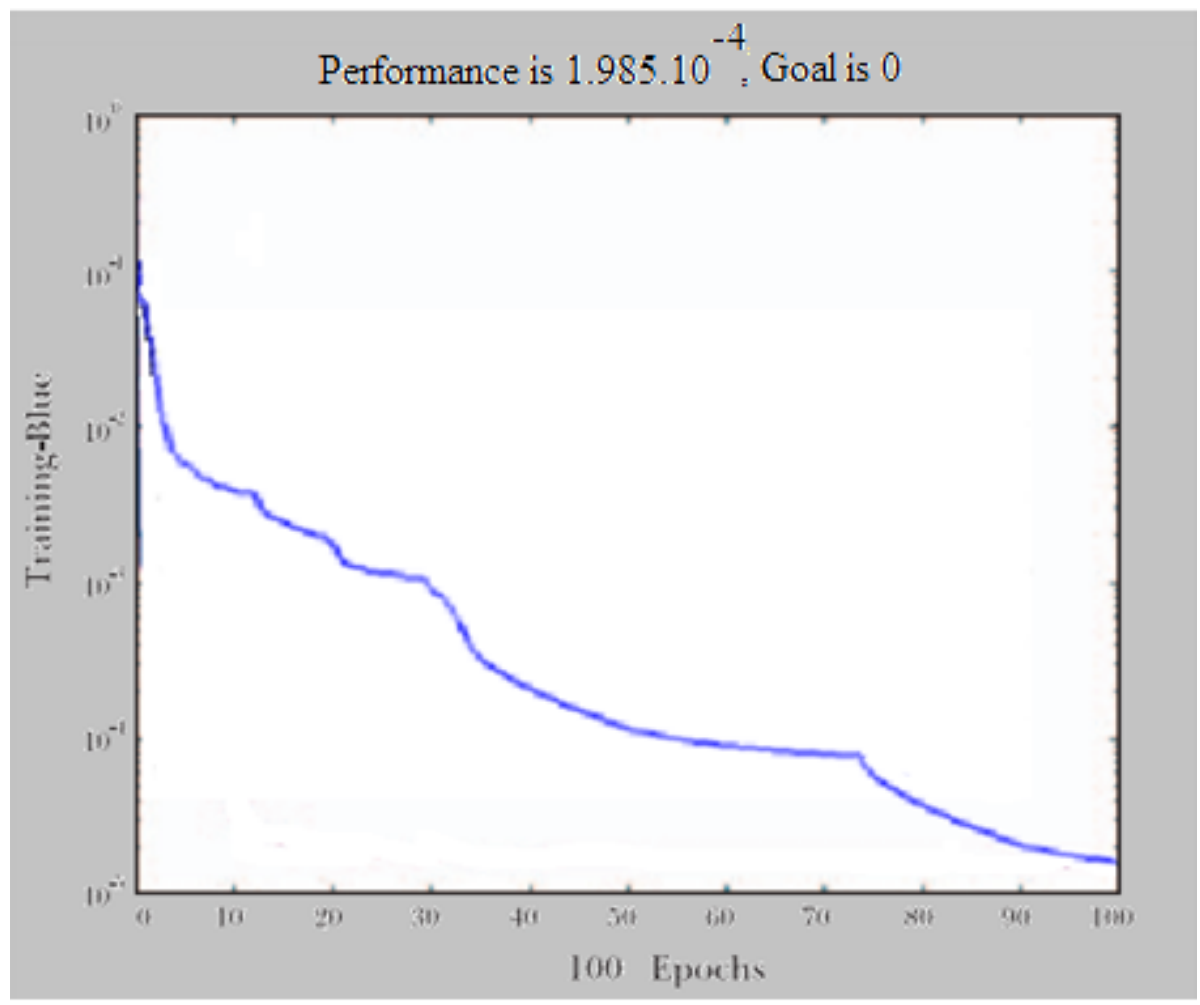

Şekil 7. Yalıtımsız duvar için YSA performans grafiği

Çizelge 2. Yalıtımsız duvar için YSA hata miktarları

\begin{tabular}{ccccc}
\hline Gerçek Değerler & YSA Değerleri & RMS & $\mathbf{R}^{\mathbf{2}}$ & $\mathbf{O Y H}$ \\
8.500 & 8.515 & 0.000155 & 0.998238 & 0.001649 \\
10.500 & 10.510 & 0.000270 & 0.999779 & 0.022123 \\
\hline 12.500 & 12.520 & 0.002652 & 0.998238 & 0.175855 \\
14.500 & 14.495 & 0.002706 & 0.998136 & 0.186020 \\
\hline 16.500 & 16.490 & 0.000834 & 0.999407 & 0.059229 \\
17.00 & 17.058 & 0.002652 & 0.999749 & 0.186020 \\
\hline 18.00 & 18.072 & 0.000944 & 0.999391 & 0.060891 \\
18.500 & 18.500 & 0.001729 & 0.999779 & 0.143873 \\
\hline 19.00 & 19.030 & 0.001504 & 0.998559 & 0.125336 \\
20.00 & 20.105 & 0.000155 & 0.999910 & 0.009037 \\
\hline
\end{tabular}

Çizelge 2'de görüldüğü gibi (1), (2) ve (3) denklemleri ile hesaplanan RMS değerleri çok düşük, $\mathrm{R}^{2}$ değeri 1'e oldukça yakın ve $\mathrm{OYH}$ değerinin düşük olduğu görülebilir.

Şekil 8'deki grafik, yapılan YSA çalışmasının yalıtımsız iç duvar sıcaklık miktarının belirlenmesinde çok yakın sonuçlar aldığını göstermektedir. Gerçek değerler ile YSA modelinden elde edilen değerlerin birbirine çok yakın olduğu görülmektedir. 


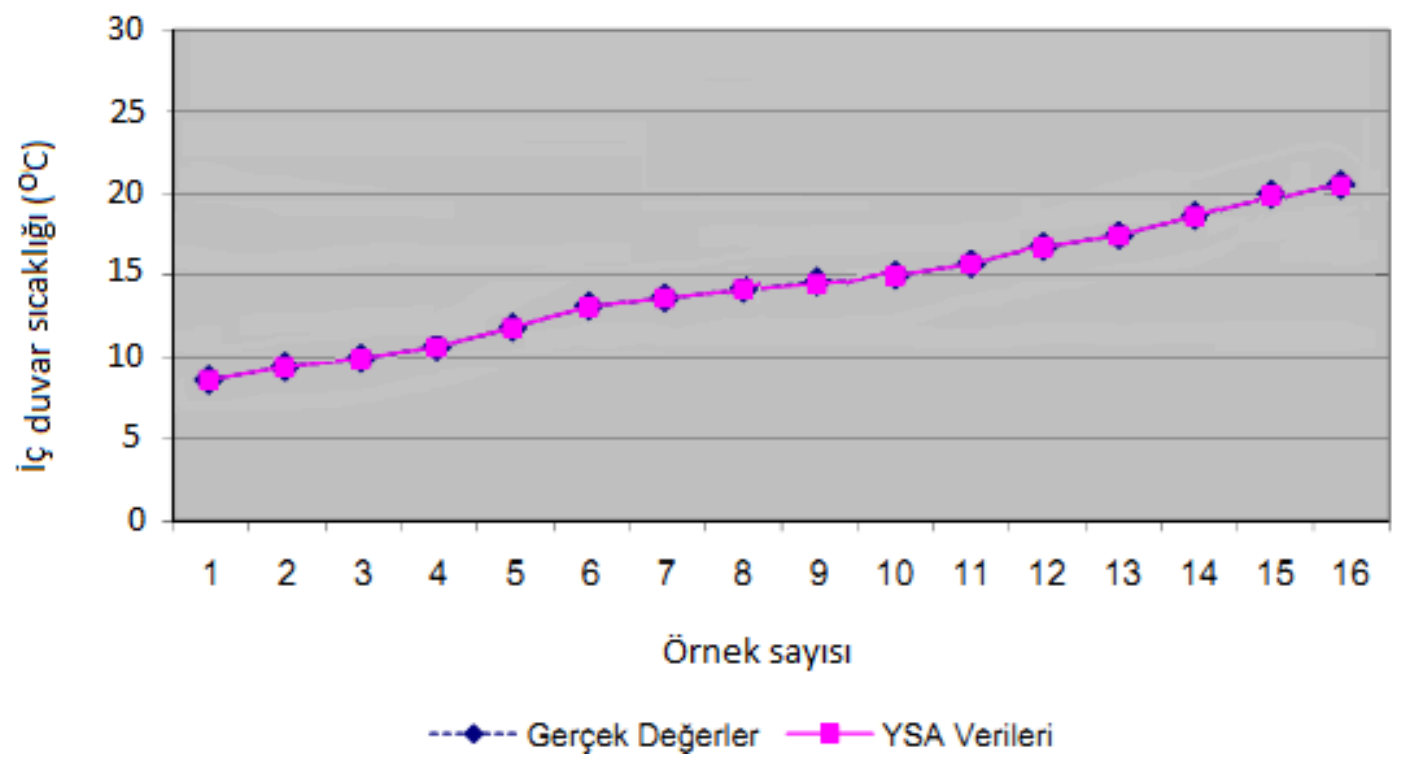

Şekil 8. Yalıtımsız duvar yapısı için iç duvar sıcaklığının YSA modelindenelde edilen sonuçlarla gerçek sonuçların karşılaştırılması

\subsubsection{Yalıtımlı duvar yapısı}

Yalıtımlı duvar bileşenleri ise, $2 \mathrm{~cm}$ iç sıva, $10 \mathrm{~cm}$ xps yalıtım malzemesi, $17 \mathrm{~cm}$ yatay delikli tuğla ve $3 \mathrm{~cm}$ dış sıvadan oluşmaktadır. Hesaplamalarda kullanılan yalıtımlı duvarın yapısı Şekil 9'da gösterilmiştir.

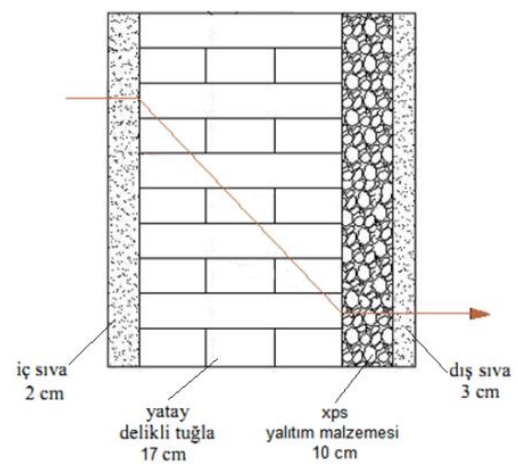

Şekil 9. Yalıtımlı duvar yapısı

\subsubsection{Yalıtımlı duvar için YSA}

Problem için 1 giriş, 1 ara ve 1 çıkış katmanı bulunan geri yayılımlı yapay sinir ağı kullanılmıştır. Şekil 10'a göre girdi katmanında 6 işlem elemanı bulunmaktadır. Ara katmanda 9 adet yapay nöron kullanılmıştır. Ağın çıkışı ise yalıtımlı duvarın iç duvar sıcaklığıdır. 


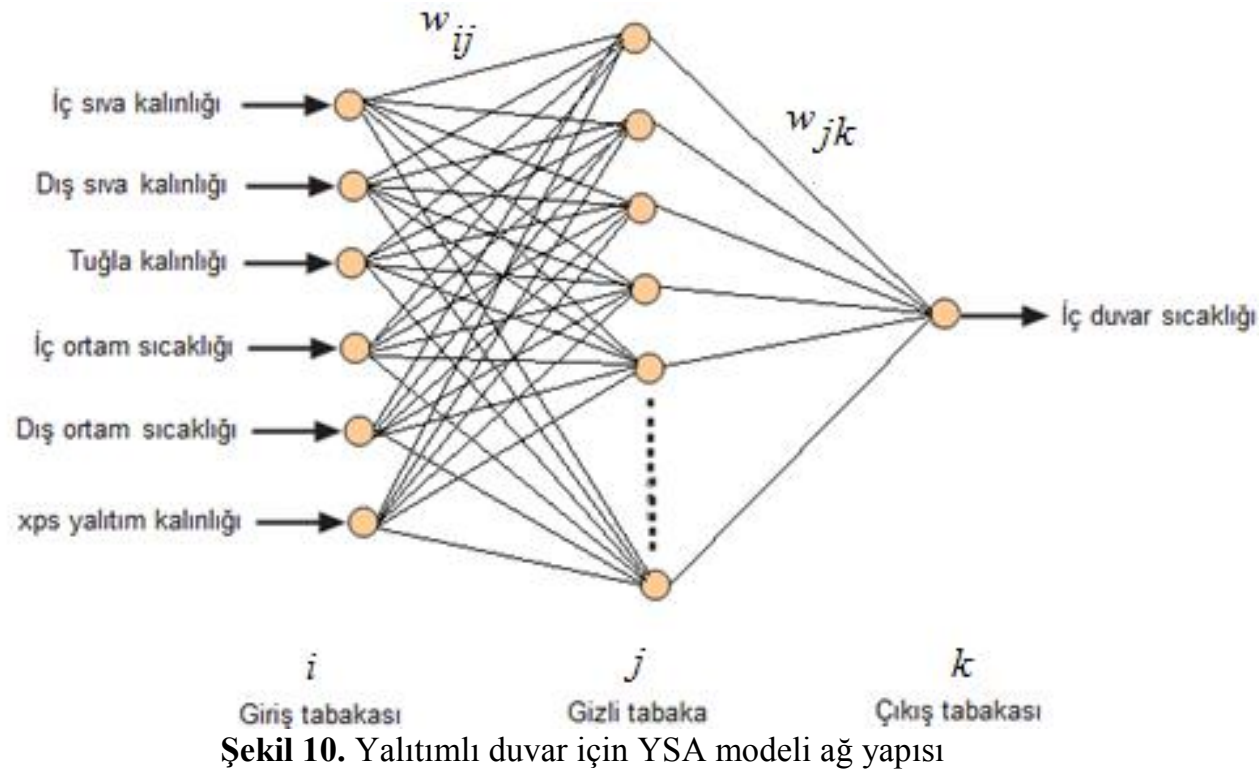

Çizelge 3'de görüleceği üzere ağın girdi elemanlarına rastgele çeşitli değerler verilerek oluşturulan eğitim ve test setinde 60 adet örnek bulunmaktadır. Bu örneklerin 30 adedi eğitim için diğer 30 adedi ise test için kullanılmıştır. Yalıtımlı duvar için yapılan 1-b uygulamada, giriş ve çıkış değerleri normalize edilmiş ve ağa tanıtılmıştır. Çeşitli ağ yapıları ve öğrenme oranları denenerek en doğru sonuç elde edilmeye çalışılmıştır. Yapılan denemeler sonucunda 9 nörondan oluşan bir ara katman uygun görülmüş, momentum katsayısı 0.979 ve öğrenme oranı 0.85 alındığında ağ daha uygun sonuçlar vermiştir.

Çizelge 3. Yalıtımlı duvar için YSA' da kullanılan eğitim ve test değerleri (İlk 30 değer YSA eğitimi, son 30 değer ise YSA testi için kullanılmıştır)

\begin{tabular}{|c|c|c|c|c|c|c|c|}
\hline \multirow[b]{2}{*}{ No } & \multicolumn{6}{|c|}{ Giriş } & \multirow{2}{*}{$\begin{array}{c}\text { Çıkıs } \\
\text { İç Duvar } \\
\text { Sicakllğı } \\
\left({ }^{\circ} \mathrm{C}\right)\end{array}$} \\
\hline & $\begin{array}{l}\text { İç Siva } \\
\text { Kalınlığ } \\
\text { (m) }\end{array}$ & $\begin{array}{l}\text { Diş Siva } \\
\text { Kalınlığı } \\
\text { (m) }\end{array}$ & $\begin{array}{l}\text { xps Yalitım } \\
\text { Kalınlığ } \\
\text { (m) }\end{array}$ & $\begin{array}{c}\text { Tuğla } \\
\text { Kalınlığ } \\
\text { (m) }\end{array}$ & $\begin{array}{c}\text { İç Ortam } \\
\text { Sicaklığ } 1 \\
\left({ }^{\circ} \mathrm{C}\right)\end{array}$ & $\begin{array}{l}\text { Diş Ortam } \\
\text { Sicaklı̆ } 1 \\
\left({ }^{\circ} \mathrm{C}\right)\end{array}$ & \\
\hline 1 & 0.01 & 0.03 & 15 & 0.15 & 18 & -6 & 13 \\
\hline 2 & 0.015 & 0.01 & 17 & 0.19 & 20 & -8 & 17.67 \\
\hline 3 & 0.02 & 0.025 & 16 & 0.17 & 19 & -9 & 21.9 \\
\hline 4 & 0.015 & 0.015 & 15 & 0.19 & 22 & -7 & 25.74 \\
\hline 5 & 0.01 & 0.03 & 18 & 0.15 & 21 & -10 & 15.73 \\
\hline 6 & 0.02 & 0.02 & 19 & 0.17 & 18 & -8 & 16.45 \\
\hline 54 & 0.015 & 0.025 & 16 & 0.19 & 19 & -9 & 18.67 \\
\hline 55 & 0.02 & 0.01 & 18 & 0.15 & 21 & -7 & 27.73 \\
\hline 56 & 0.01 & 0.015 & 17 & 0.17 & 20 & -8 & 23.69 \\
\hline 57 & 0.015 & 0.02 & 19 & 0.19 & 22 & -10 & 30.01 \\
\hline 58 & 0.02 & 0.025 & 15 & 0.17 & 21 & -9 & 19.39 \\
\hline 59 & 0.01 & 0.015 & 2051 & 0.15 & 19 & -6 & 15.78 \\
\hline 60 & 0.015 & 0.03 & 2050 & 0.19 & 18 & -8 & 17.97 \\
\hline
\end{tabular}

Yapay sinir ağını eğittikten ve test ettikten sonra, problem için verilen değerler ağa sunulursa elde edilen iç yüzey sıcaklığı $19.80^{\circ} \mathrm{C}$ olarak bulunur. Bu problemin sayısal çözümü sonucunda elde edilen iç yüzey sıcaklığı $19.82{ }^{\circ} \mathrm{C}$ 'dir [9]. 
Ağın eğitimi tamamlandıktan sonra ağın performansını test etmek amacıyla eğitim setindeki örneklerden tamamen farklı değerler kullanılarak ağ test edilmiş ve bulunan sonuçlar Çizelge 4'de karşılaştırılmıştır. Çizelge 4 incelendiğinde yapılan YSA modelinin performansının oldukça iyi olduğu görülebilir. Burada RMS değerleri çok düşük, $\mathrm{R}^{2}$ değeri 1'e oldukça yakın ve OYH değerinin düşük oluğu görülebilir.

Çizelge 4. Yalıtımlı duvar için YSA hata miktarları

\begin{tabular}{ccccc}
\hline Gerçek Değerler & YSA Değerleri & RMS & $\mathbf{R}^{\mathbf{2}}$ & OYH \\
\hline 13.00 & 13.10 & 0.002652 & 0.999749 & 0.186020 \\
15.730 & 15.805 & 0.000944 & 0.999391 & 0.060891 \\
17.760 & 17.681 & 0.001729 & 0.998745 & 0.175855 \\
19.390 & 19.989 & 0.002706 & 0.998136 & 0.143873 \\
21.900 & 21.910 & 0.000834 & 0.999407 & 0.059229 \\
23.690 & 23.645 & 0.000155 & 0.998238 & 0.001649 \\
25.740 & 25.751 & 0.000270 & 0.999779 & 0.022123 \\
27.730 & 27.742 & 0.000028 & 0.998559 & 0.009037 \\
19.00 & 19.030 & 0.001504 & 0.999910 & 0.125336 \\
30.01 & 30.00 & 0.000322 & 0.999984 & 0.025063 \\
\hline
\end{tabular}

Şekil 11'degerçek sıcaklık değerleri ile YSA modelinden elde edilen sıcaklık değerlerinin birbirine çok yakın olduğunu ve yapılan YSA çalışmasının, yalıtımlı iç duvar sıcaklık miktarının belirlenmesinde çok yakın sonuçlar aldığını göstermektedir.

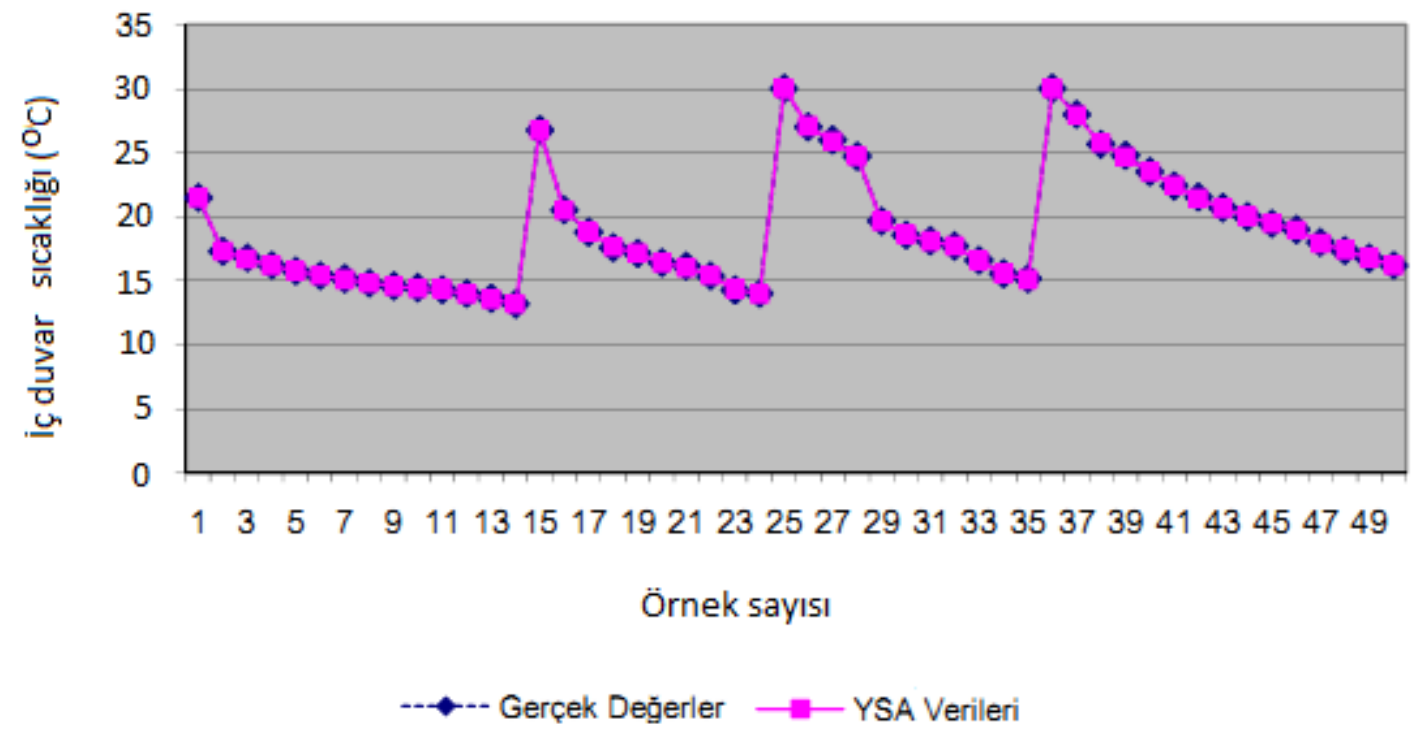

Şekil 11. Yalıtımlı duvar yapısı için iç duvar sıcaklığının YSA modelinden elde edilen sonuçlarla gerçek sonuçların karşılaştırılması

Aktivasyon fonksiyonu olarak tangent sigmoid fonksiyonu, ağın eğitilmesi için öğrenme tipi olarak danışmanlı öğrenme uygulanmıştır. $\mathrm{Bu}$ parametreler kullanılarak MATLAB'ta hazırlanan programda YSA eğitilir. Matlab programı ağırlık değerlerini rastgele belirleyip her bir örneği sırasıyla ağa sunarak çalışmaktadır. Bu ağın iterasyona bağlı hata değişimi ve performans grafiği Şekil 12'de verilmiştir. 


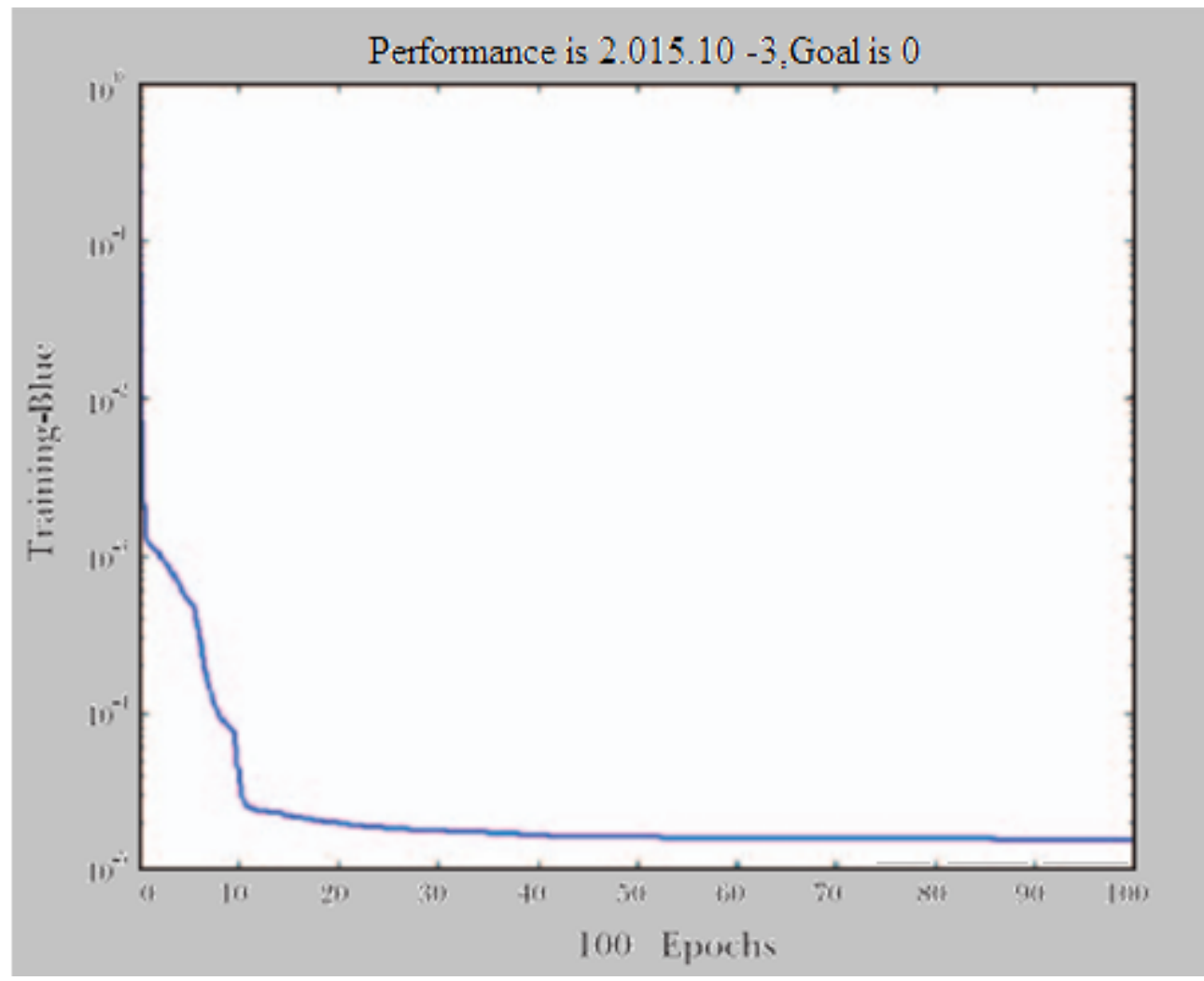

Şekil 12. Yalıtımlı duvar için YSA performans grafiği

\subsection{Boru Yapısı}

Yalıtımsız bir boruda 1sı kaybı daha fazladır ve hesabı net ve hassas değildir. Çünkü borunun bulunduğu ortamın cinsi ve sıcaklığı, boru yüzeyine doğrudan değişkenlik göstererek temas eder. Cihaz 1şımaları, hava akımı ve rüzgar şiddeti, sulu ortam ise su sıcaklığı, korozyon gibi etkenler önemlidir. En önemlisi ise bu değerlerin sabit olmaması ve ölçme zorluğudur.

\subsubsection{Yalıtımsız boru yapısı}

Şekil 13'de gösterilen yalıtımsız borudaki 1sı kaybı, tahmin konusunda başarılı sonuçlar veren YSA kullanılarak tespit edilmiştir. Yapılan uygulamada referans olarak boru çapı $100 \mathrm{~mm}$, boru iç sıcaklığ $150{ }^{\circ} \mathrm{C}$ ve diş ortam sıcaklığ $15^{\circ} \mathrm{C}$ alınmıştır.

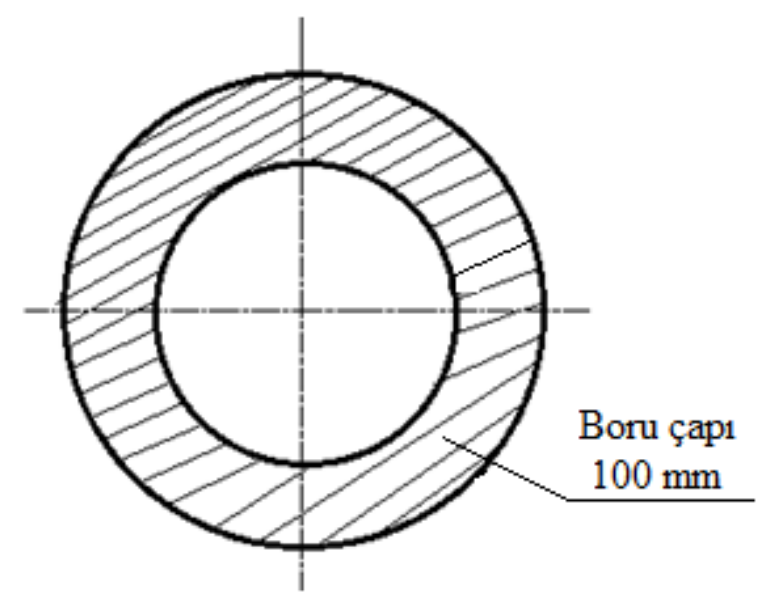

Şekil 13. Yalıtımsız boru yapısı 


\subsubsection{Yalıtımsız boru yapısı için YSA}

Bu uygulamada kullanılan YSA'da Şekil 14'de görüldüğü gibi 3 girdi, 1 çıktı ve 7 adet nörondan oluşan 1 gizli katman kullanılmıştır.

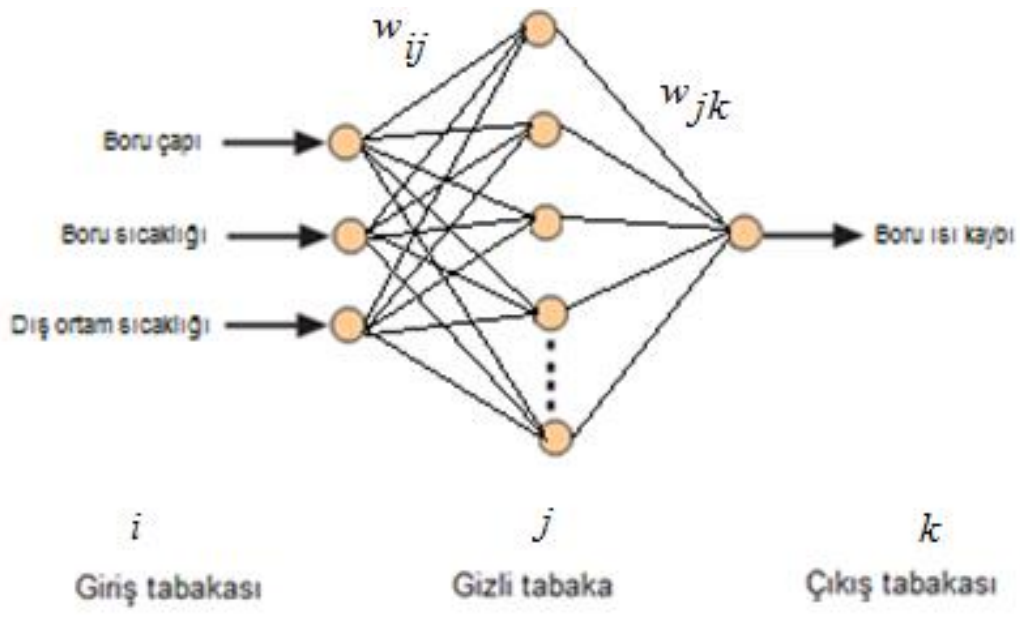

Şekil 14. Yalıtımsız boru için YSA modeli ağ yapısı

Yalıtımsız boru için YSA'da kullanılan eğitim ve test değerleri Çizelge 5'de verilmiştir. Burada 60 adet veri örneklendirilmiş, bunların 30 adedi eğitim için, diğer 30 adedi ise test için kullanılmıştır. Bu değerler ağa sunulurken normalize edilmiştir. Boru 1sı kayıpları, seçilen boru çapına göre TSE çizelgelerinden alınmıştır [9].

Çizelge 5. Yalıtımsız boru için YSA'da kullanılan eğitim ve test değerleri (Uygulama No: 2-a, İlk 30 değer YSA eğitimi, son 30 değer ise YSA testi için kullanılmıştır)

\begin{tabular}{ccccc}
\hline No & $\begin{array}{c}\text { Boru Çapı } \\
(\mathrm{m})\end{array}$ & $\begin{array}{c}\text { Goru Sicaklığı } \\
\left({ }^{\circ} \mathrm{C}\right)\end{array}$ & $\begin{array}{c}\text { Dış Ortam Sıcaklığı } \\
\left({ }^{\circ} \mathrm{C}\right)\end{array}$ & $\begin{array}{c}\text { Çıkış } \\
\text { Boru Isı Kaybı } \\
(\text { Kcal/mh })\end{array}$ \\
\hline 1 & 0.05 & 300 & 10 & 500 \\
2 & 0.15 & 150 & 15 & 1500 \\
3 & 0.20 & 225 & 20 & 2000 \\
4 & 0.25 & 300 & 25 & 1000 \\
5 & 0.05 & 375 & 30 & 2500 \\
6 & 0.10 & 75 & 15 & 3000 \\
54 & 0.20 & 225 & 20 & 1500 \\
55 & 0.25 & 75 & 30 & 2500 \\
56 & 0.15 & 150 & 10 & 1000 \\
57 & 0.10 & 375 & 25 & 3500 \\
58 & 0.25 & 300 & 15 & 1500 \\
59 & 0.15 & 225 & 30 & 500 \\
60 & 0.20 & 375 & 20 & 3000 \\
\hline
\end{tabular}

Yapılan denemeler sonucunda bir ara katman uygun görülmüş, momentum katsayısı 0.98 ve öğrenme oranı 0.75 olarak seçildiğinde ağ daha uygun sonuçlar vermiştir. Bu parametrelerin kullanıldığı ağ, Matlab ortamında geliştirilen programla eğitilmiş ve test edilmiştir. Matlab programı ağırlık değerlerini rastgele belirleyip her bir örneği sırasıyla ağa sunarak çalışmaktadır. Bu ağın iterasyona bağlı performans grafiği Şekil 15 'de verilmişstir. 


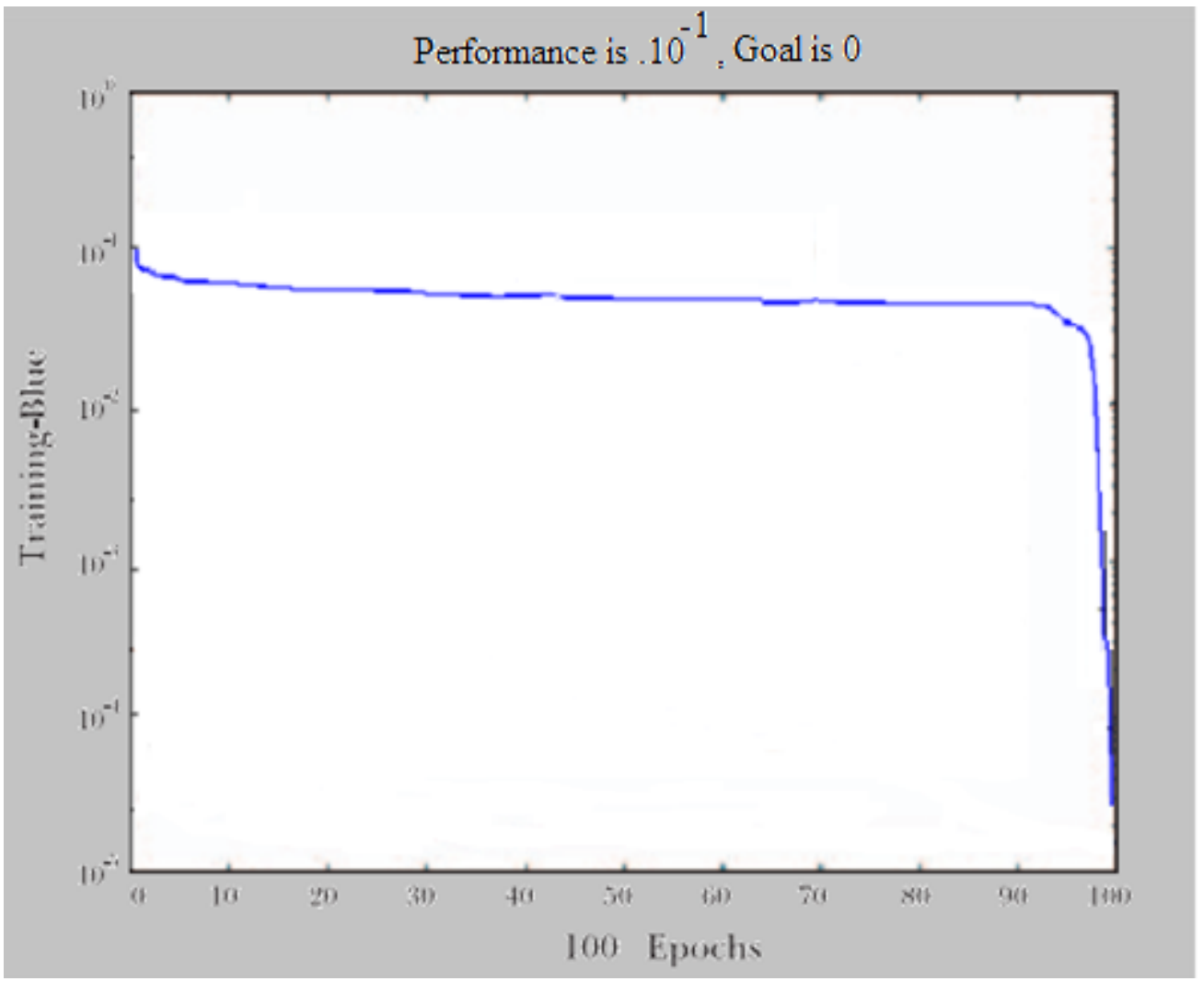

Şekil 15. Yalıtımsız boru için YSA performans grafiği

Çizelge 5'de verilen eğitim setinin uygulanması sonucu borudaki 1sı kaybı $2000.010 \mathrm{kcal} / \mathrm{mh}$ bulunmuştur. Bu problemin çözümü neticesinde $2000 \mathrm{kcal} / \mathrm{mh}$ olarak bulunmuştur [9]. Sonuç göz önüne alındığında yapay sinir ağından yeterli hassasiyette bir sonuç elde edildiği görülür. Çizelge 6 incelendiğinde yapılan YSA modelinin performansının oldukça iyi olduğu görülebilir. (1), (2) ve (3) denklemleri sonucunda elde edilen RMS değerleri çok düşük, $\mathrm{R}^{2}$ değeri 1'e oldukça yakın ve OYH değerinin düşük olduğu görülebilir.

Çizelge 6. Yalıtımsız boru için YSA hata miktarları

\begin{tabular}{rrccc}
\hline Gerçek Değerler & YSA Değerleri & RMS & $\mathbf{R}^{\mathbf{2}}$ & OYH \\
\hline 500.010 & 500.017 & 0.000270 & 0.999984 & 0.001649 \\
1000.15 & 1000.19 & 0.000028 & 0.999391 & 0.060891 \\
1500.014 & 1500.016 & 0.002652 & 0.998238 & 0.175855 \\
2000.00 & 2000.010 & 0.002706 & 0.998136 & 0.186020 \\
2500.025 & 2500.349 & 0.000834 & 0.999407 & 0.059229 \\
3000.50 & 3000.65 & 0.000322 & 0.999749 & 0.025063 \\
3500.00 & 3500.018 & 0.000270 & 0.999779 & 0.022123 \\
1250.050 & 1250.065 & 0.001729 & 0.999749 & 0.186020 \\
2750.150 & 2750.125 & 0.001504 & 0.999391 & 0.060891 \\
3250.650 & 3250.950 & 0.000155 & 0.999407 & 0.175855 \\
\hline
\end{tabular}

Çizelge 6'ya göre boru 1sı kaybı değerleri ile YSA modelinden elde edilen değerlerin birbirine çok yakın olduğu, yani yalıtımsız boru ısı kaybı miktarının belirlenmesinde çok yakın sonuçlar aldı̆̆1 görülmektedir. 
Şekil 16'daki grafik incelendiğinde, gerçek yalıtımsız boru 1sı kaybı değerleri ile YSA modelinden elde edilen değerlerin birbirine çok yakın olduğu, burada yapılan YSA çalışmasının, yalıtımlı boru ısı kaybı miktarının belirlenmesinde çok yakın sonuçlar aldığı görülmektedir.

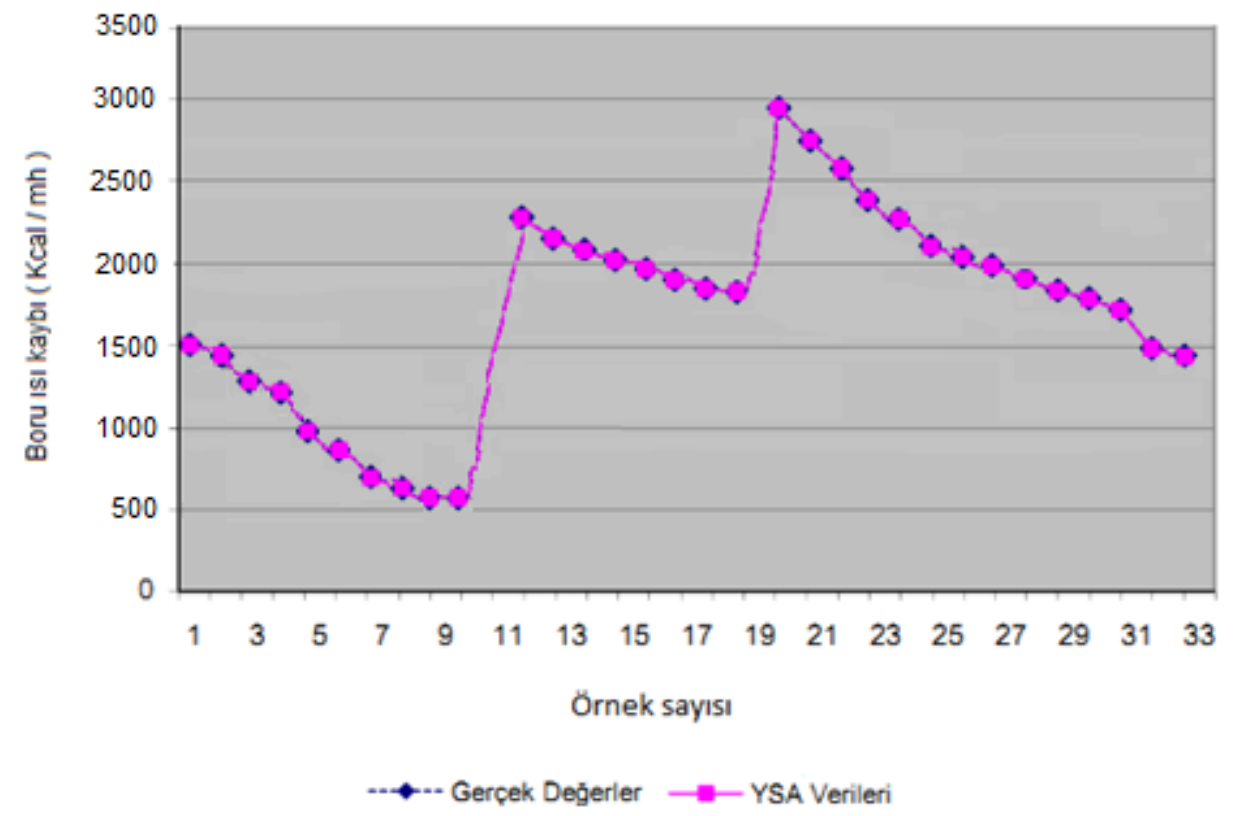

Şekil 16. Yalıtımsız boru yapısı için ısı kaybının YSA modelinden elde edilen sonuçlarla gerçek sonuçların karşılaştırılması

\subsubsection{Yalıtımlı boru yapısı}

Bu uygulamada $100 \mathrm{~mm}$ 'lik referans boru çap1, $150{ }^{\circ} \mathrm{C}$ 'lik boru sıcaklığg 1 ve $15^{\circ} \mathrm{C}$ ' lik diş ortam sıcaklığındaki bir boru 200 mm kalınlığında bir yalıtım malzemesi ile yalıtılmıştır (Şekil 17).

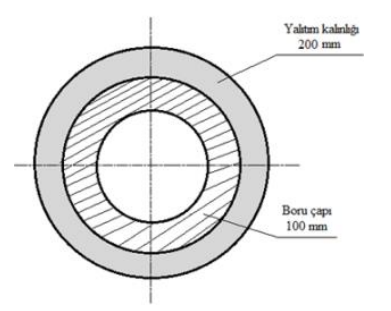

Şekil 17. Yalıtımlı boru yapısı

\subsubsection{Yalıtımlıboru yapısı için YSA}

Bu uygulamada kullanılan YSA'da Şekil 18'de görüldüğü gibi 4 girdi, 1 çıktı ve 8 adet nörondan oluşan 1 gizli katman kullanılmıştır. Ağın girdi elemanlarına çeşitli değerler verilerek oluşturulan eğitim setinde 25 adet örnek bulunmaktadır.

Ağın eğitim setinde kullanılan değerler Çizelge 7'de verilmiştir. Geri yayılımlı bir yapay sinir ağı kullanılarak boruda oluşan 1sı kaybı tespit edilmiştir. Bu örnekler ağa sunulurken değerler normalize edilmiştir. Yapılan denemeler sonucunda bir ara katman uygun görülmüş, momentum kat sayısı 0.98 ve öğrenme oranı 0.8 olarak seçildiğinde ağ daha uygun sonuçlar 
vermiştir. Bu parametrelerin kullanıldığı ă Matlab ortamında geliştirilen programla eğitilmiş ve test edilmiştir.

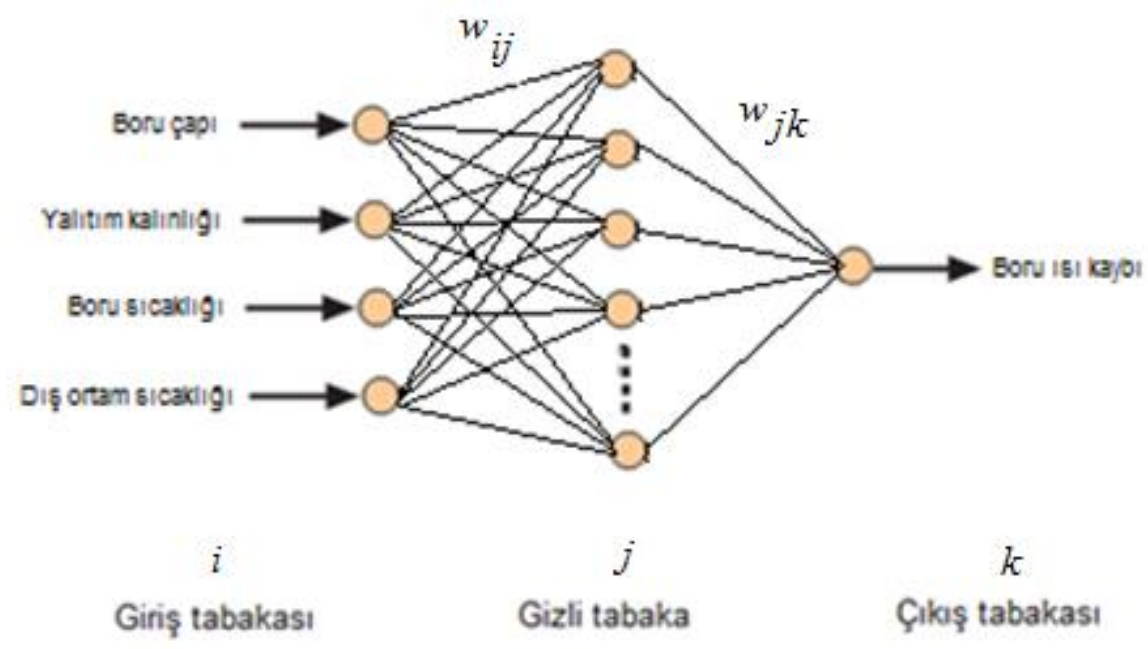

Şekil 18. Yalıtımlı boru için YSA modeli ağ yapısı

Çizelge 7. Yalıtımlı boru için YSA dakullanılan eğitim ve test değerleri (Uygulama No: 2-b, İlk 30 değer YSA eğitimi, son 30 değer ise YSA testi için kullanılmıştır)

\begin{tabular}{c|cccc|c}
\hline No & $\begin{array}{c}\text { Boru Çapı } \\
(\mathrm{m})\end{array}$ & $\begin{array}{c}\text { Yalıtım Kalınlı̆̆ } \\
(\mathrm{m})\end{array}$ & $\begin{array}{c}\text { Giriş } \\
\text { Boru Sıcaklığı } \\
\left({ }^{\circ} \mathrm{C}\right)\end{array}$ & $\begin{array}{c}\text { Dış Ortam Sıcaklı̆̆ } 1 \\
\left({ }^{\circ} \mathrm{C}\right)\end{array}$ & $\begin{array}{c}\text { Çıkış } \\
\text { Boru Isı Kaybı } \\
(\text { Kcal/mh })\end{array}$ \\
\hline 1 & 0.45 & 0.1 & 300 & 10 & 50 \\
2 & 0.50 & 0.3 & 150 & 15 & 150 \\
3 & 0.40 & 0.15 & 250 & 20 & 75 \\
4 & 0.25 & 0.2 & 300 & 25 & 100 \\
5 & 0.35 & 0.25 & 350 & 5 & 125 \\
6 & 0.25 & 0.35 & 200 & 15 & 100 \\
54 & 0.30 & 0.25 & 200 & 20 & 150 \\
55 & 0.25 & 0.1 & 250 & 5 & 50 \\
56 & 0.45 & 0.35 & 150 & 10 & 100 \\
57 & 0.30 & 0.15 & 350 & 25 & 150 \\
58 & 0.25 & 0.3 & 300 & 15 & 75 \\
59 & 0.35 & 0.2 & 200 & 5 & \\
60 & 0.40 & 0.1 & 150 & 20 & \\
\hline
\end{tabular}

Bu problemde 0.8 öğrenme oranı ve Çizelge 9'da verilen eğitim setinin uygulanması sonucu yalıtımlı borunun 1sı kaybı $100.029 \mathrm{Kcal} / \mathrm{mh}$ olarak bulunmuştur. Bu problemin çözümü neticesinde yalıtımlı borunun 1sı kaybı $100.034 \mathrm{Kcal} / \mathrm{mh}$ bulunmuştur [9]. Buna göre sonuca yeterli hassasiyette yaklaşıldığı görülmüştür.

Bu ağın iterasyona bağlı hata değişimi Şekil 19'da verilmiştir. Şekil 19 incelendiğinde yapılan YSA modelinin performansının oldukça iyi olduğu görülmektedir. 


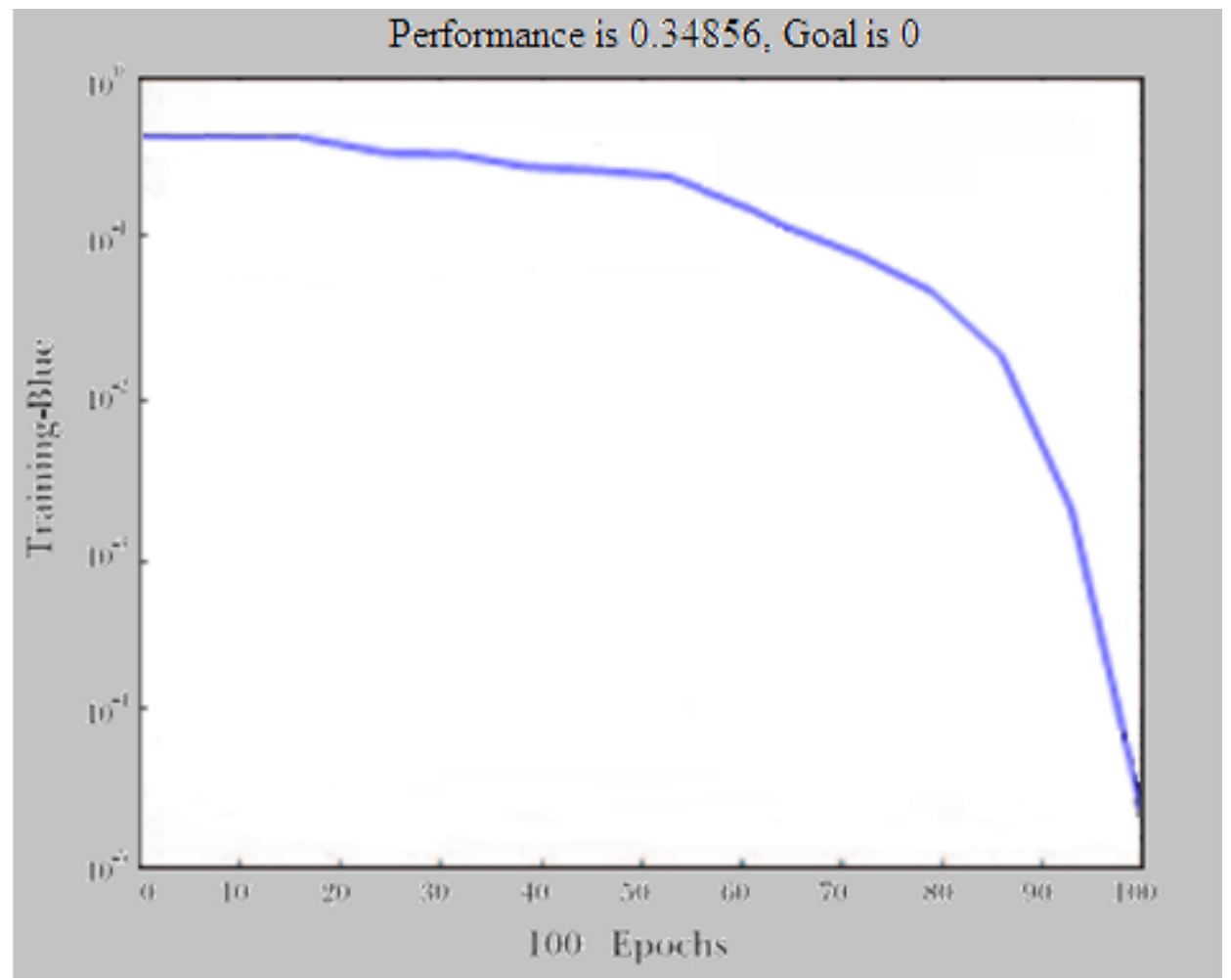

Şekil 19. Yalıtımlı boru için YSA performans grafiği

Matlab programı ağırlık değerlerini rastgele belirleyip her bir örneği sırasıyla ağa sunarak çalışmaktadır. Ağın test dataları ve test sonuçlarının karşılaştırılması Çizelge 8'de verilmiştir. Burada yapılan YSA modelinin performansının oldukça iyi olduğu görülmektedir. (1), (2) ve (3) denklemleri ile hesaplanan RMS değerleri çok düşük, $\mathrm{R}^{2}$ değeri 1'e oldukça yakın ve OYH değerinin düşük olduğu görülebilir. Gerçek boru yalıtım kalınlığı 100 mm ye karşın YSA'nın aynı değeri $100.015 \mathrm{~mm}$ olduğu tablodan görülmektedir. Diğer verilen gerçek boru parametrelerine [9] karşılık YSA ağının yakın değerler tahmin ettiği Çizelge 10'da ve gerçek 1sı kayıpları ile YSA’nın tahmin ettiği ısı kayıplarının biri birine ne kadar yakın olduğu da Şekil 20’de görülmektedir.

Çizelge 8. Yalıtımlı boru için YSA hata miktarları

\begin{tabular}{rrrcc}
\hline Gerçek Değerler & YSA Değerleri & RMS & $\mathbf{R}^{\mathbf{2}}$ & OYH \\
\hline 50.024 & 50.078 & 0.000834 & 0.999407 & 0.059229 \\
75.00 & 75.020 & 0.000155 & 0.998238 & 0.001649 \\
100.034 & 100.029 & 0.002652 & 0.998238 & 0.175855 \\
125.078 & 125.093 & 0.002706 & 0.998136 & 0.186020 \\
150.038 & 150.084 & 0.000834 & 0.999407 & 0.059229 \\
150.00 & 150.029 & 0.000322 & 0.999749 & 0.025063 \\
125.010 & 125.027 & 0.000270 & 0.999779 & 0.022123 \\
100.00 & 100.015 & 0.000028 & 0.998559 & 0.009037 \\
75.013 & 75.018 & 0.001504 & 0.998745 & 0.125336 \\
50.00 & 50.016 & 0.000155 & 0.999910 & 0.009037 \\
\hline
\end{tabular}

Şekil 20'deki grafik incelendiğinde, gerçek yalıtımlı boru 1sı kaybı değerleri ile YSA modelinden elde edilen değerlerin bir birine çok yakın olduğu, burada yapılan YSA 
çalışmasının yalıtımlı boru 1sı kaybı miktarının belirlenmesinde çok yakın sonuçlar aldığı görülmektedir.

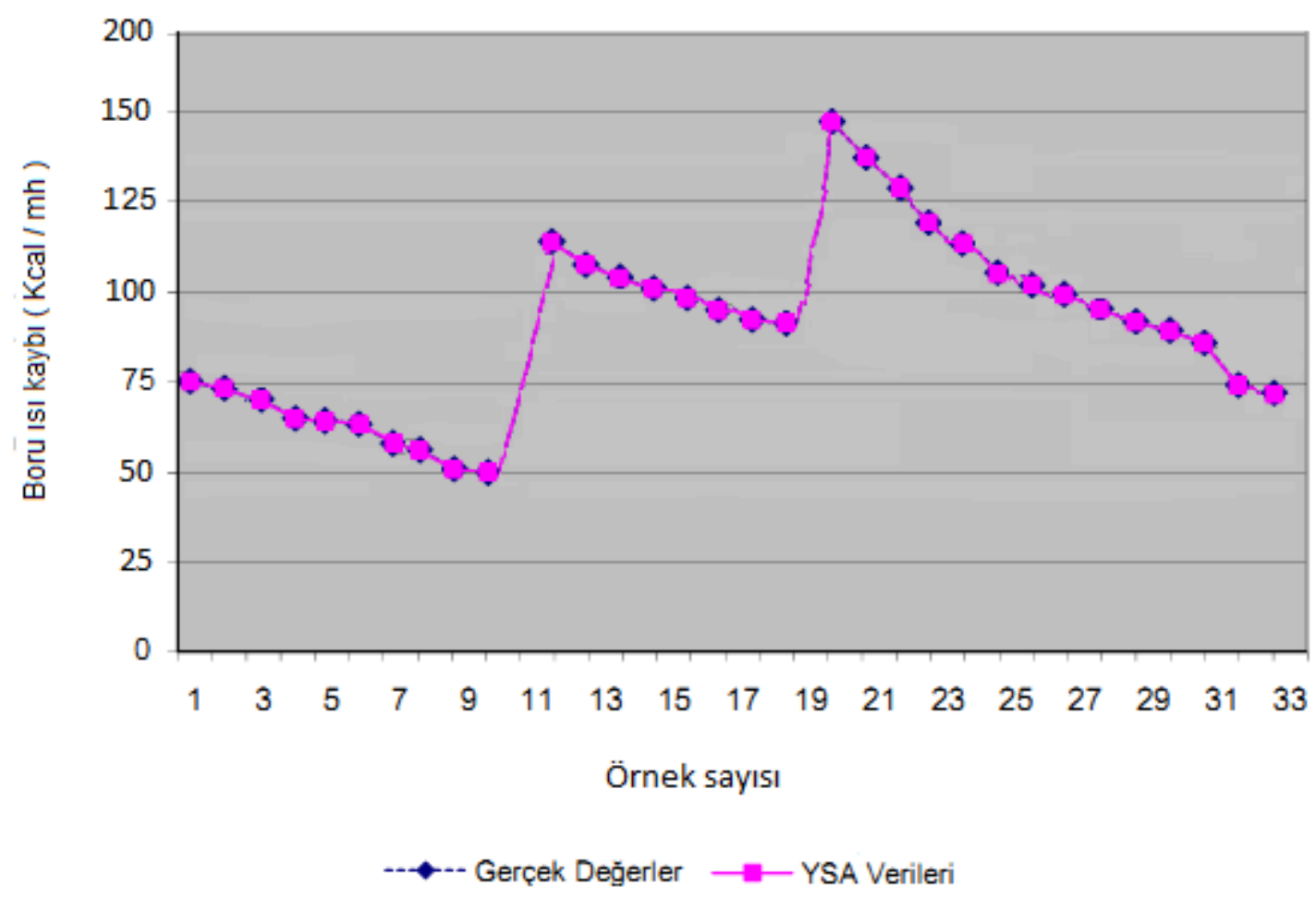

Şekil 20. Yalıtımlı boru yapısı için ısı kaybının YSA verileri ile gerçek verilerin karşılaştırılması

\section{SONUÇ}

$\mathrm{Bu}$ çalışmanın 1-a ve 1-b uygulamasında, yalıtımlı ve yalıtımsız duvardaki ısı kaybının incelenmesi için iki ayrı YSA modeli kullanılmıştır. Duvar, iç sıva, dış sıva, yalıtım malzemesi kalınlık değerleri ile iç ve dış ortam sıcaklıkları giriş değerleri olarak tanımlanmış; iç duvar sıcaklığı ise çıkış değeri olarak ağa sunulmuştur.2-a ve 2-b uygulamasında ise yalıtımlı ve yalıtımsız borudaki sıcaklık ve boru çapına bağlı olarak oluşan 1sı kaybı incelenmiştir. Yapay sinir ağlı modeli kurularak yapılan bu çalışmada yaklaşık ve hassas sonuçlar elde edilmiştir. Yani rastgele ve periyodik zaman aralığı içinde iç sıva kalınlığı $2 \mathrm{~cm}$, dış sıva kalınlığı $3 \mathrm{~cm}$ olan ve $17 \mathrm{~cm}$ duvar genişliğine göre, ayrıca $10 \mathrm{~cm}$ kalınlığında yalıtımlı (xps malzeme yalıtımlı) ve yalıtımsız duvar parametrelerine göre [9] tablodan alınan değerler ile bu tablodan alınan doğrusal olmayan yani bir formüle dayanmadan oluşturulan istatiksel veriler YSA ağ yapısına tanıtıldıktan sonra ve eğitildikten sonra Matlab ortamında YSA modelinden test edilerek alınan sonuçlar karşılaştırılmış ve biri birine çok yakın değerler tespit edilmiştir. Yine rastgele ve periyodik zaman aralığı içinde $100 \mathrm{~mm}$ boru boyutuna göre yalıtımlı (stropiyer malzeme yalıtımlı) ve yalıtımsız boru parametrelerine göre [9] tablodan alınan değerler ile YSA modelinden alınan sonuçlar karşılaştırılmış ve biri birine çok yakın değerler tespit edilmiştir. 


\section{KAYNAKLAR}

[1] M.Ö. Ültanır, 21. Yüzyıla Girerken Türkiye’nin Enerji Stratejisinin Değerlendirilmesi, Yayın No: TÜSİAD-T/98-12/239 (TÜSİAD Yayınları, İstanbul, 2013).

[2] J. Wang, B. Malakooti, A Feed for wardneural network for multiple criteria decision making. Computers Operations Research, 19:2 (1992) 151-167.

[3] A.M. Flitman, Towards probabilistic foot tipping: A hybrid approach utilising genetically defined neural networks and linear programming, Computer Operating Research, 33:7 (2006) 2003-2022.

[4] Ö. Keleşoğlu, A. Fırat, Tuğla Duvardaki ve Tesisattaki Isı Kaybının Yapay Sinir Ağları İle Belirlenmesi, Frat Üniv. Fen ve Müh. Bil. Dergisi, 18 (1) (2006) 133-141.

[5] M. Gölcü, A. Dombaycı, S. Abalı, Denizli için optimum yalıtım kalınlı̆̆ının enerji tasarrufuna etkisi ve sonuçları, Gazi Üniv. Müh. Mim. Fak. Der., 21(4) (2006) 639-644.

[6] A. Bolattürk, Determination of optimum insulation thickness for building walls with respect to various fuels and climate zones in Turkey, Applied Thermal Engineering, 26 (11-12) (2006) 1301-1309.

[7] K. Çomakl1, B. Yüksel, Optimum insulation thickness of external walls for energy saving, Applied Thermal Engineering, 23 (4) (2003) 473-479.

[8] S. Öztuna, E. Dereli, Edirne ilinde optimum duvar yalıtım kalınlı̆̆ının enerji tasarrufuna etkisi, Trakya Univ. J. Sci., 10(2) (2009) 139-147.

[9] T.H. Karakoç, E. Binyıldız, O. Turan, Binalarda ve Tesisatta Isı Yalıtımı, No: G20 (ODE Teknik Yayınları, 1999).

[10]B. Cirak, R. Kozan, Prediction of the Coating Thickness of Wire Coating Extrusion Processes Using ANN, Journal of Modern Applied Science, 3(7) (2009) 52-67.

[11] Ş.Ö. Şahin, Yapay sinir ağları yardımı ile dinamik bir senaryo analizi, Doktora tezi, İTÜ Fen Bilimleri Enstitüsü, İstanbul, 2001.

[12]S. Wang, N.P. Archer, A neural network technique in modelling multiple criteria multiple person decision making, Computers Operations Research, 21:2 (1993) 127-142.

[13]B. Çırak, Plastik Boru Üretimi Prosesinde Ekstrüzyon parametrelerinin YSA ile incelenmesi, Dicle Üniversitesi Fen Bilimleri Enstitüsü Dergisi, 3(1) (2014) 33-42.

[14]Ç. Elmas, Yapay Sinir Ağları (Seçkin Yayıncılık, Ankara, 2003). 